theo mùa, tăng cao vào các tháng cuối năm. Phòng khám đã triển khai 7 chuyên khoa từ năm 2016 đến 2018, tỷ lệ cao nhất ở phòng khám Nội tổng hợp và phòng khám Tai Mũi Họng.

Lời cảm ơn: Nghiên cứu này nhận được sự hỗ trợ lớn từ Sở Y tế Tp. Hồ Chí Minh và Bệnh viện Quận Thủ Đức trong quá trình thực hiện.

\section{TÀI LIÊU THAM KHẢO}

1. Lê Quang Cường, Lý Ngọc Kính, Khương Anh Tuấn, Trân Thị Mai Oanh, Trịnh Ngọc Thành, Nguyễn Thị Minh Hiếu, et al. (2011) Nghiên cứu thực trạng quá tải, dưới tải của hệ thống bệnh viện các tuyến và đề xuất giải pháp khắc phục, httips://goo.gl/IzlXef,

2. Lương Văn Sinh, Đinh Thanh Hưng, Nguyễn Văn Tập (2017) "Mô hình bệnh tật tại bệnh viện Quận Tẩn Phú năm 2016". Tạp chí Ý học Việt Nam, tr.207-213.

3. Nguyễn Quang Vinh, Lê Thị Mỹ Hạnh (2019) "Mô hình bệnh tât của bẹnh nhân đến khám và điệu trị ngoại trú tại Bệnh viện Quận Bình Thạnh, Thành phố Hî̀ Chí Minh, năm 2017". Tạp chí Y học thực hành, Số 10 (1114), 98-101.

4. Nguyển Lê Thục Đoan, Nguyễn Thanh Hiệp (2019) "Thực trạng triển khai mô hình trạm y tế hoạt động theo nguyên lý y học gia đình tại thành phố Hồ Chí Minh giai đoan 2018 - 2019". Tạp chí Y học cô̂ng đồng, Số 1 (54), 119-123.

5. Nguyển Thị Hồng, Nguyễn Minh Quân (2019) "Xác định mô hình bệnh tật ở các bệnh nhân điêu trị nội trú tại Bệnh viện Quận Thủ Đức giai đoạn 2014 2018". Tạp chí Y học thực hành, Số 10 (1114), 73-78.

6. Nguyễn Văn Vỹy, Nguyển Thanh Bình, Võ Thị Kìm Anh (2020) "Sự hài lòng của người bệnh và môt số yếu tố liên quản đến sứ dụng dịch vụ Khám chữa bệnh tại các trạm y tế huyện Bàu Bàng, Bình Dương năm 2019". Tạp chí Y học cộng đồng, Số 1 (54), 54-61.

7. Nguyễn Tô Bảo Hoàng, Dương Đình Công (2020) "Cơ cấu bênh tât người bểnh điều trị tại Bệnh viện Đa khoa Sài Gòn thành phố Hồ Chí Minh nẳm 2016-2018". Tạp chí Y học cộng đồng, Số 1 (54), 3-8.

8. Irence C.Kuo (2013) "Satellite clinics in academic ophthalmology programs: an exploratory study of successes and challenges ". BMC Ophthalmology, 13 (79), pp.1-6.

9. Jennifer Hamm, Lee Hilliard, Thomas Howard, Jeffrey Lebensburger (2016) "Maintaining High Level of Care at Satellite Sickle Cell Clinics". Journal of Health Care for the Poor and Underserved, 27 (1), 280-292.

\title{
KHẢO SÁT CÁC TỔN THƯƠNG BÀN TAY Ở BỆNH NHÂN ĐÁI THÁO ĐƯỜNG TYPE 2 TẠI BỆNH VIỆN BƯU ĐIỆN
}

\section{TÓM TẮT}

Mục tiêu: Khảo sát các tổn thương bàn tay ở bệnh nhân đái tháo đường type 2 và một số yếu tố liển quan đến các tổn thương đó. Đối tượng và phương pháp nghiên cứu: Naghiên cứu mổ tả cắt ngang với 91 bệnh nhân có tổn thương cổ bàn tay trên 1054 bệnh nhân đái tháo đường đến khám tại khoa Nội tổng hợp, bệnh viện Bưu Điện. Đánh gía tổn thương bàn cổ tay dựa trên điểm đau VAS, thang điểm BOSTON, hội chứng ống cổ tay; đánh giá tổn thương gân dạng dài duỗi ngắn, gân gấp và dây thần kinh giữa qua siêu âm. Kết quả: Tỷ lệ tồn thương bàn cổ tay trên bệnh nhân đái tháo đường type 2 là $8,6 \%$. Tỷ lệ tổn thương các cấu trúc giải phấu vùng cổ bàn tay là: 70,3\% tôn thương gân gấp; 60,4\% tổn thương dây thần kinh giữa, 6,6\% tổn thương khớp, 2,2\% tổn thương gân dạng dài duỗi ngắn. Đặc điểm lấm sàng tổn thương vưng bàn cổ tay: Chủ yếu bệnh nhân có cường độ đau vừa với $70,3 \%$, sau đó là đau ít là

\footnotetext{
${ }^{1}$ Bệnh viện Bưu Điện

2Trường Đại học Y Hà Nội

Chịu trách nhiệm chính: Nguyễn Vĩnh Ngọc

Email: vinhngoc@hmu.edu.vn

Ngày nhận bài: 6.8.2021

Ngày phản biện khoa học: 5.10 .2021

Ngày duyệt bài: 14.10.2021
}

\section{Lê Minh Thuận ${ }^{1}$, Nguyễn Vĩnh Ngọc ${ }^{2}$}

$12,1 \%$ và ít nhất là đau nhiều với $2,2 \%$; giá trị trung bình thang điểm VAS là $3.76 \pm 1.86$; mức độ hạn chế vận đô̂ng, cảm giác BOSTON đạt giá trị $1.34 \pm 0.56$; trên siêu âm thây $60,5 \%$ có tổn thương dây thần kinh giữa với diên tích trung bình là: 11.487 土 $2.195 \mathrm{~mm}$. Các yếu tố lên quan đến tổn thương bàn cổ tay là sự kiểm soát đường huyết; chỉ số HbA1c; tuổi, thời gian mắc bệnh, tiền sử tăng huyết áp và tình trạng thừa cân béo phì. Kết luận: Tỷ lệ tổn thương bàn cổ tay ở bệnh nhân đái tháo đương là $8,63 \%$; Tổn thương vừng cổ tay chủ yếu là tổn thương gân gấp $(70,3 \%)$; tổn thương dây thần kinh giữa $(60,4 \%)$. Các yếu tố liên quan đến tổn thương vùng bàn cổ tay là: tình trang kiểm soát đường huyết, chỉ số HbA1c, tuổi tác, thời gian mắc bệnh, tiển sử tăng huyết áp và thừa cân béo phì.

Tư khóa: đái tháo đường, tổn thương bàn cổ tay, gân gấp, gân dạng dài duỗi ngắn, dây thần kinh giữa

\section{SUMMARY}

\section{SURVEY OF HAND INJURIES IN PATIENTS TYPE 2 DIABETES MELITUS AT THE HOSPITAL \\ OF POST AND TELECOMMUNICATIONS}

Objective: To investigate hand injuries in patients with type 2 diabetes mellitus and some factors related to such lesions. Methods: A cross-sectional descriptive study with 91 patients with wrist lesions on 1054 diabetic patients who visited the Department of 
General Internal Medicine, Hospital of Post and Telecommunications. Evaluation of wrist injury based on VAS pain score, BOSTON scale, carpal tunnel syndrome; assessment of damage to the long and short extensor of the thumb tendons, the flexor tendons and the median nerve by ultrasound. Results and Conclusion: The rate of wrist injury in patients with type 2 diabetes is $8.6 \%$. The rate of injury to the anatomical structures of the wrist is: $70.3 \%$ damage to the flexor tendon; $60.4 \%$ injured the median nerve, $6.6 \%$ damaged joints, $2.2 \%$ damaged the long and short tendons. Clinical characteristics of hand and wrist injuries: Most of the patients had moderate pain intensity with $70.3 \%$, followed by little pain with $12.1 \%$ and at least a lot of pain with $2.2 \%$; average value of VAS scale is $3.76 \pm 1.86$; the degree of movement restriction, the BOSTON sensation reached the value of $1.34 \pm 0.56$; On ultrasound, $60.5 \%$ had damage to the median nerve with the average area: $11,487 \pm 2,195 \mathrm{~mm}$. The factors associated with wrist injury are glycemic control; HbA1c index; age, duration of disease, history of hypertension and overweight.

Keywords: diabetes mellitus, hand injury, flexor tendon, long and short extensor of the thumb tendon, median nerve.

\section{I. Đă̆T VẤN ĐỀ}

Vẫn đề cần quan tâm hiện nay trong điều trị bênh đái tháo đường (ĐTĐ) là không chỉ phát hiện sớm và kiểm soát tốt đường huyết mà còn phải theo dõi điều trị biến chứng cấp tính, mạn tính của bệnh, trong đó có các biến chứng cơ xương - khớp ${ }^{1}$. Nhiêuu nghiên cứu gần đây cho thấy biến chứng cơ - xương - khớp ở bệnh nhân ĐTĐ tương đối cao, đặc biệt là chi trên khi mạch máu và thần kinh vùng bàn - cổ tay rất dễ bi à ảnh hưởng, do phần mềm mạch máu nuôi dưỡng gân cơ vùng bàn - cổ tay lại rất nghèo nàn ${ }^{2,3}$

Tác giả Suzan M.Attar thực hiện một nghiên cứu cắt ngang từ tháng $6 / 2010$ đển tháng 6/2011 tại Bệnh viện Đại học King Abdulaziz, A Rập cho thấy $17,9 \%$ bệnh nhân ĐTÐ có biến chứng cơ - xương - khớp và phổ biến nhất là hội chứng ống cổ tay với $17,67 \%$ và có sự liên quan với những bênh nhân lao đông chân tay, thừa cân, có biến chứng mạch máu ${ }^{4}$. Nghiên cứu của Tariq Ahmed Bhat năm 2016 trên 403 bệnh nhân đái tháo đường và 300 bệnh nhân nhóm chứng ở một vùng tại Ấn Độ cho thấy: Gần $20 \%$ bệnh nhân ĐTÐ có biến chứng bàn tay so với $5 \%$ bệnh nhân không mắc ĐTÐ có tổn thương; sự khác biệt này có ý nghĩa thống kê. Từ đây, tác giả cũng kết luận rằng biến chứng cơ - xương khớp ở bệnh nhân ĐTĐ type 2 khá cao, đặt biệt là vù̀ng bàn cổ tay ${ }^{5}$.

Ở Việt Nam cũng đã có một số nghiên cứu về tổn thương phần mềm cổ bàn tay, tuy nhiên với số lượng bệnh nhân còn hạn chế, và còn ít nghiên cứu đi sâu vào việc khảo sát các tổn thương bàn tay ở bệnh nhân đái tháo đường type 2. Vì vâyy chúng tôi thực hiện đề tài: "Khảo sát các tổn thương bàn tay ở bệnh nhân Đái tháo đường type 2 tại Bệnh viện Bưu Điện" được tiến hành với hai mục tiều:

1. Nhân xét tỷ lệ và đăc điểm các tôn thương bàn cổ tay ở bênh nhân đái tháo đường type 2 .

2. Đánh giá một số yêu tố liên quan đến các tôn thương trên.

\section{II. ĐỐI TƯỢNG VÀ PHƯƠNG PHÁP NGHIÊN CỨU \\ Thiết kế nghiên cứu: Nghiên cứu mô tả cắt} ngang.

\section{Đối tượng nghiên cứu:}

Tiêu chuẩn lựa chọn: Bệnh nhân khám chữa bệnh nội trú và ngoại trú được chẩn đoán xác định mắc bệnh đái tháo đường theo hướng dẫn của Bộ Y tế năm 2017 và Tổ chức Hiệp hội Đái tháo đường Hoa Kỳ ${ }^{6}$. Từ đó chúng tổi tiểp tục chọn ra bệnh nhân có triệu chứng tổn thương bàn cổ tay trên lâm sàng như: Đau,tê vùng bàn cổ tay, hạn chế gấp bàn ngón tay, sưng đau vùng mỏm trâm quay, đau khi tăng vận động ngón cái, biến dạng vùng cổ bàn tay.

Tiêu chuẩn loại trừ: Bệnh nhân có tình trang tăng đưởng huyết do các bênh lý khác, có tổn thương bản cổ tay do bệnh lý khác, có tiền sử can thiệp vùng bàn cổ tay, có tiền sử bệnh về tâm thần và không đồng ý tham gia nghiên cứu

Cỡ mẫu nghiên cứu: Toàn bộ bệnh nhân đái tháo đường có tổn thương bàn cổ tay. Trong thời gian nghiên cứu từ tháng 8 năm 2020 đến tháng 8 năm 2021, có 1054 bệnh nhân đái tháo đường, trong đó có 91 bệnh nhân có tổn thương bàn cố tay.

Các chỉ số biến số: Đánh gía tổn thương bàn cổ tay dựa trên điểm đau VAS, thang điểm BOSTON, hội chứng ống cổ tay; đánh giá tổn thương gân dạng dài duối ngắn, gân gấp và dây thần kinh giữa qua siêu âm.

Xử lí số liệu: Các số liệu được phân tích theo phương pháp thống kê y học, tìm mối liên quan dự trên tỷ suất chênh $\mathrm{OR}$. Số liệu được làm sạch và xử lý bằng phần mềm SPSS26.

\begin{tabular}{|c|c|c|c|}
\hline & c điểm & $\begin{array}{c}\text { Số lượng } \\
(\mathbf{N}=91)\end{array}$ & $\begin{array}{l}\text { Tỷ lệ } \\
(\%)\end{array}$ \\
\hline Giới & Nam & 35 & 38,5 \\
\hline tính & Nữ & 56 & 61,5 \\
\hline Đô & 40-49 tuối & 2 & 2,2 \\
\hline tuổi & 50-59 tuối & 10 & 11,0 \\
\hline
\end{tabular}




\begin{tabular}{|c|c|c|c|}
\hline & 60-69 tuối & 21 & 23,1 \\
\hline & $\begin{array}{l}\text { Từ } 70 \text { tuối } \\
\text { trở lên }\end{array}$ & 58 & 63,7 \\
\hline Đột & i trung bình & & 98 \\
\hline & Dưới 1 năm & 5 & 5,5 \\
\hline gian & $\begin{array}{l}\text { Từ } 1 \text { năm } \\
\text { đến } 5 \text { năm }\end{array}$ & 18 & 19,8 \\
\hline bệnh & $\begin{array}{l}\text { Mắc bênh } \\
\text { trên } 5 \text { năm }\end{array}$ & 68 & 74,7 \\
\hline & Gầy & 2 & 2,2 \\
\hline BMI & Thừa cân & 65 & 71,4 \\
\hline & Béo phì & 24 & 26,4 \\
\hline & $\begin{array}{l}\text { Tăng huyết } \\
\text { áp }\end{array}$ & 79 & 86,8 \\
\hline $\begin{array}{l}\text { Tiền } \\
\text { sử }\end{array}$ & $\begin{array}{c}\text { Rối loạn mõ } \\
\text { máu }\end{array}$ & 52 & 57,1 \\
\hline & Hút thuốc lá & 26 & 28,6 \\
\hline & Béo phì & 27 & 29,7 \\
\hline
\end{tabular}

Nhận xét. Hâu hết người bệnh ở độ tuối tù̀ 70 tuổi trở lên chiếm 63,7\%. Độ tuổi trung bình là 70.08 土 7.98 (năm). Bệnh nhân nữ chiếm ưu thế $(61,5 \%)$. Thời gian mắc bệnh trên trên 5 năm là $74,7 \%$. Tỷ lệ thừa cân là $26,4 \%$. Gần $90 \%$ người bệnh có tiền sử tăng huyết áp, tiếp đó là rối loạn mõ máu với $57,1 \%$; béo phì với $29,7 \%$.

\begin{tabular}{|c|c|c|c|}
\hline \multicolumn{2}{|c|}{ Đăc điếm lâm sànq } & \multirow{2}{*}{$\frac{\text { Số lượng }}{77}$} & \multirow{2}{*}{$\begin{array}{c}\text { Tỷ lệ (\%) } \\
84,5\end{array}$} \\
\hline \multirow{4}{*}{\begin{tabular}{|c} 
Triệu \\
chứng \\
biểu \\
hiệ̂ lâm \\
sàng \\
\end{tabular}} & Đau tự nhiên & & \\
\hline & Đau về đêm & 3 & 3,3 \\
\hline & Giảm cảm giác & 18 & 19,8 \\
\hline & $\begin{array}{l}\text { Dấu hiệu } \\
\text { Dukan }\end{array}$ & 23 & 25,4 \\
\hline \multirow{3}{*}{$\begin{array}{l}\text { Sưng } \\
\text { khớp }\end{array}$} & Cố tay & 4 & 4,4 \\
\hline & Bàn ngón & 2 & 2,2 \\
\hline & Ngón xa & 1 & 1,1 \\
\hline \multicolumn{2}{|c|}{$\begin{array}{c}\text { Hạn chế vận động gấp } \\
\text { duỗi }\end{array}$} & 72 & 79,1 \\
\hline
\end{tabular}

Nhân xét: Có đến 84,5\% người bệnh có biểu hiện đau tự nhiên. Chỉ có 25,4\% người bệnh thực hiện nghiệm pháp Dukan dương tính; 19,8\% giảm cảm giác ở bàn cổ tay. Gần $80 \%$ người bệnh có hạn chế vận động gấp duỗi.

Bảng 3: Cường độ đau và mức độ hạn chế vận động, cảm giác BOSTON của đôî tượng nghiên cứu

\begin{tabular}{|c|c|c|c|}
\hline \multicolumn{2}{|c|}{ Đặc điểm } & $\begin{array}{c}\text { Số lượng } \\
\text { (N=91) }\end{array}$ & $\begin{array}{c}\text { Tỷ lề } \\
\text { (\%) }\end{array}$ \\
\hline \multirow{2}{*}{$\begin{array}{c}\text { Phân loaii } \\
\text { cương } \\
\text { độ đau } \\
\text { VAS }\end{array}$} & $\begin{array}{c}\text { Không đau } \\
\text { (0 điểm) }\end{array}$ & 14 & 15,4 \\
\cline { 2 - 4 } & $\begin{array}{c}\text { Đau ít (1-3 điếm) } \\
\text { Đau vửa (4-6 } \\
\text { điểm) }\end{array}$ & 11 & 12,1 \\
\cline { 2 - 4 } & Đau nhiều & 2 & 70,3 \\
\hline
\end{tabular}

\begin{tabular}{|c|c|c|}
\hline (7-10 điếm) & & \\
\hline Điểm VAS trung bình & 91 & $\begin{array}{c}3.76 \pm \\
1.86\end{array}$ \\
\hline $\begin{array}{c}\text { Điểm BOSTON trung bình } \\
\text { vận động- cảm giác }\end{array}$ & 55 & $\begin{array}{c}1.34 \pm \\
0.56\end{array}$ \\
\hline
\end{tabular}

Nhận xét: Chủ yếu bệnh nhân có cường độ đau vừa với $70,3 \%$, sau đó là đau ít là $12,1 \%$ và đau nhiều với $2,2 \%$. Mức độ đau của người bênh ở mức độ nhe với giá trị trung bình thang điểm VAS là $3.76 \pm 1.86$. Mức độ hạn chế vận động, cảm giác BOSTON đạt giá trị $1.34 \pm 0.56$.

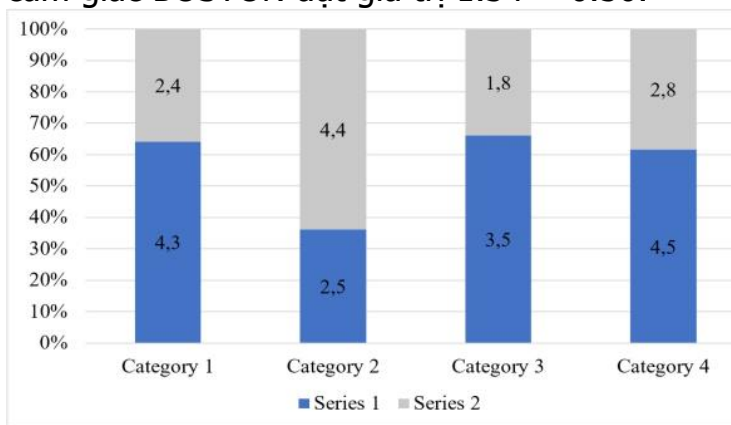

Biểu đồ 1. Phân loại các dạng tổn thương của bểnh nhân

Nhận xét: Chủ yếu là tổn thương gân gấp (70,3\%), tổn thương dây thần kinh giữa $(60,4 \%)$.

Bảng 4. Kích thước dây thần kinh giứa của đôî́ tượng nghiên cứu.

\begin{tabular}{|c|c|c|}
\hline $\begin{array}{c}\text { Kích thước dây } \\
\text { thân kinh giữa }\end{array}$ & $\begin{array}{c}\text { Số lượng } \\
\text { tồn thương }\end{array}$ & $\begin{array}{c}\text { Diện tích } \\
\text { trung bình }\end{array}$ \\
\hline $\begin{array}{c}\text { Diện tích dây thần } \\
\text { kinh giữa đâuu gần } \\
\text { (mm2) }\end{array}$ & 55 & $11.487 \pm$ \\
$(60,4 \%)$ & 2,195 \\
\hline
\end{tabular}

Nhận xét: Diện tích trung bình của dây thần kinh giữa là $11.487 \pm 2,195 \mathrm{~mm} 2$. Kết quả ghi nhận trên 55 người bệnh có tổn thương dây thần kinh giữa với $60,4 \%$

Bảng 5. Các yêu tô liên quan đến tổn thương khớp bàn cổ tay của người bệnh

\begin{tabular}{|c|c|c|c|}
\hline \multirow{3}{*}{ Đặc điểm } & \multicolumn{2}{|c|}{ Tốn thương khớp } & \multirow{3}{*}{\begin{tabular}{|c|} 
OR \\
$(95 \% \mathrm{CI})$
\end{tabular}} \\
\hline & Có & Không & \\
\hline & n (\%) & n (\%) & \\
\hline \multicolumn{4}{|c|}{ Chỉ số BMI } \\
\hline Thừa cân & $3(12,5)$ & $21(87,5)$ & \multirow{2}{*}{$\begin{array}{c}3,048 \\
(1,571- \\
16,262)\end{array}$} \\
\hline Không thừa cân & $3(4,5)$ & $64(95,5)$ & \\
\hline & & & \multirow{3}{*}{$\begin{array}{c}0,118 \\
(0,021- \\
0,667)\end{array}$} \\
\hline Có & $3(3,8)$ & $76(96,2)$ & \\
\hline Không & $3(25,0)$ & $9(75,0)$ & \\
\hline \multicolumn{4}{|c|}{ Chỉ số Glucose } \\
\hline $\begin{array}{l}\text { Kiếm soát } \\
\text { chưa tốt }\end{array}$ & $4(6,7)$ & $56(93,3)$ & \multirow{3}{*}{$\begin{array}{c}1,036 \\
(1,017- \\
5,994) \\
\end{array}$} \\
\hline Kiếm soát tốt & $2(6,5)$ & $29(93,5)$ & \\
\hline \multicolumn{3}{|c|}{ Chỉ số HbA1c } & \\
\hline
\end{tabular}




\begin{tabular}{|c|c|c|c|}
\hline $\begin{array}{c}\text { Kiếm soát chưa } \\
\text { tốt }\end{array}$ & $4(7,0)$ & $53(93,0)$ & $\begin{array}{c}1,208 \\
(1,02-\end{array}$ \\
\cline { 1 - 3 } Kiếm soát tốt & $1(5,9)$ & $32(94,1)$ & $6,971)$ \\
\hline
\end{tabular}

Nhận xét: Những người thừa cân sẽ có tổn thương khớp bàn cổ tay gấp 3,048 lần so với những người bệnh không bị thừa cân $(95 \%$ CI: 1,571-16,262). Người bệnh kiểm soát đường huyết và chỉ số HbA1c chưa tốt sẽ có tổn thương khớp bàn tay nhiều gấp 1,036 lần $(95 \% \mathrm{CI}$ : $1,017-5,994)$ và 1,208 (95\%CI: $1,02-6,971)$ lần so với người kiểm soát tốt.

Bảng 6. Các yếu tồ liên quan đến tổn thương gân gấp bàn cồ tay

\begin{tabular}{|c|c|c|c|}
\hline \multirow{3}{*}{ Đặc điểm } & \multicolumn{2}{|c|}{ Tốn thương khớp } & \multirow{3}{*}{$\begin{array}{c}\text { OR }(95 \% \\
\text { CI })\end{array}$} \\
\hline & Có & Không & \\
\hline & $\mathrm{n}(\%)$ & $n(\%)$ & \\
\hline \multicolumn{4}{|c|}{ Tuối } \\
\hline $\begin{array}{c}\text { Dưới } 40 \text { đến } \\
69 \text { tuổi }\end{array}$ & $19(57,6)$ & $14(42,4)$ & \multirow{2}{*}{\begin{tabular}{|c}
0,392 \\
$(0,155-$ \\
$0,99)$
\end{tabular}} \\
\hline Từ 70 trở lên & $45(77,6)$ & $13(22,4)$ & \\
\hline \multicolumn{4}{|c|}{ Thời gian mắc bệnh } \\
\hline Dưới 5 năm & $13(56,5)$ & $10(43,5)$ & \multirow{2}{*}{$\begin{array}{c}0,433 \\
(1,016- \\
1,167) \\
\end{array}$} \\
\hline Trên 5 năm & $51(75,0)$ & $17(25,0)$ & \\
\hline \multicolumn{4}{|c|}{ Tăng huyết áp } \\
\hline Có & $59(74,7)$ & $20(25,3)$ & \multirow{2}{*}{\begin{tabular}{|c|}
4,130 \\
$(1,178-$ \\
$14,483)$
\end{tabular}} \\
\hline Không & $5(41,7)$ & $7(58,3)$ & \\
\hline \multicolumn{4}{|c|}{ Glucose } \\
\hline $\begin{array}{l}\text { Kiếm soát } \\
\text { chưa tốt }\end{array}$ & 43 & $17(28,3)$ & \multirow{2}{*}{$\begin{array}{c}1,204 \\
(1,047- \\
3,081)\end{array}$} \\
\hline Kiếm soát tốt & $2167,7)$ & $10(32,3)$ & \\
\hline
\end{tabular}

Nhận xét: Những bệnh nhân dưới 69 tuổi có tổn thương gân gấp chỉ bằng 0,392 lần người từ 70 tuổi trở lên $(95 \% \mathrm{CI}: 0,155-0,99)$ và những người mắc bệnh dưới 5 năm có tổn thương gân gấp chỉ bằng 0,433 người mắc bệnh trên 5 năm (1,016-1,167). Với những người bệnh có tiền sử tăng huyết áp có tổn thương gân gấp cao gấp 4,13 lần so với những người không có tiền sử này $(95 \% \mathrm{CI}$ : 1,178-14,483). Người bệnh kiểm soát đường huyết chưa tốt sẽ tổn thương gân gấp cao gấp 1,204 lần so với những người kiểm soát tốt đường huyết (95\%CI: 1,047-3,081)

Bảng 7. Các yếu tố liên quan đến tôn thương dây thần kinh giữa bàn cổ tay của người bênh

\begin{tabular}{|c|c|c|c|}
\hline \multirow{2}{*}{ Đặc điểm } & \multicolumn{2}{|c|}{ Tốn thương khớp } & \\
\cline { 2 - 3 } & Có & Không & OR $(95 \%$ \\
\cline { 2 - 3 } & $\mathrm{n}(\%)$ & $\mathrm{n}(\%)$ & $\mathrm{CI})$ \\
\hline \multicolumn{3}{|c|}{ Thời gian mắc bệnh } \\
\hline Dưới 5 năm & $13(56,5)$ & $10(43,5)$ & $\begin{array}{c}0,805 \\
(1,309- \\
2,099)\end{array}$ \\
\hline Trên 5 năm & $42(61,8)$ & $26(38,2)$ & \\
\end{tabular}

\begin{tabular}{|c|c|c|c|}
\hline \multicolumn{4}{|c|}{ Chỉ số BMI } \\
\hline Thừa cân & Thừa cân & Thừa cân & 1,125 \\
\cline { 1 - 2 } Không thừa câr & Không & Không & $(1,031-$ \\
& thừa cân & thừa cân & $2,938)$ \\
\hline
\end{tabular}

Nhận xét: Người bệnh có thời gian mắc bệnh dưới 5 năm có tổn thương dây thần kinh giữa chỉ bằng 0,805 lần ( $95 \%$ CI: 1,309-2,099) so với người mắc trên 5 năm. Và người thừa cân sẽ có tổn thương gấp 1,125 lần so với người không thừa cân (95\%CI: 1,031-2,938).

\section{BÀN LUÂN}

Đái tháo đường, nếu không được chẩn đoán sớm và điều trị kịp thời, sẽ gây ra rất nhiều biến chứng, bao gồm biến chứng cấp và mạn tính trên nhiều cơ quan bộ phận: mắt, tim mạch, thận, bệnh lý động mạch ngoại vi, thần kinh,... 3,4. Bên cạnh đó, biến chứng về cơ xương khớp liên quan đến đái tháo đường ngày càng được quan tâm nhiều hơn, trong đó có tổn thương vùng bàn cổ tay?.

Trong tổng số 1054 người bênh đái tháo đường tham gia nghiên cứu có 91 người có tổn thương bàn cổ tay. Tỷ lệ này chiếm $8,63 \%$ thấp hơn nghiên cứu tại Ấn Độ năm 2016 với 19,8\% bị tổn thương, chủ yếu tập trung vào: hạn chế vận động khớp, bệnh Dupuytren, ngón tay lò xo, hội chứng đường hầm cổ tay, hội chứng Dequervain ${ }^{4}$. Với 91 người bệnh này có tuổi trung bình là $70.08 \pm 7.98$, tỷ lệ tổn thương ở nữ $(61,5 \%)$ cao hơn ở nam $(38,5)$, chỉ số BMI chủ yếu là thừa cân với $74,7 \%$. Phần lớn người dân mắc bệnh trên 5 năm với $74,7 \%$, tiền sử chủ yếu là tăng huyết áp với $86,8 \%$ và tiếp đó là rối loạn mõ máu là $57,1 \%$. Kết quả này phản ánh đúng thực tại khi chủ yếu người bệnh hấu hết tử 70 tuổi trở lên với $63,7 \%$. Người cao tuổi mắc bênh đái tháo đường thường sẽ có thời gian mắc bểnh cao, bên cạnh đó các bệnh mạn tính thường liên quan đến nhau nên có tiền sử tăng huyết áp cao và rối loạn mõ máu cao.

Triệu chứng lâm sàng chủ yếu của người bệnh là đau tự nhiên với $84,5 \%$. Tuy nhiên, kết quả có thể lẫn với các triệu chứng của bệnh khác vì hầu hết đối tượng là người cao tuổi, mắc nhiều bệnh mạn tính. Khi thực hiện nghiệm pháp Dukan đặc trứng với tổn thương bàn cổ tay có kết quả $25,4 \%$ dương tính. Cùng với đó các triệu chứng giảm cảm giác ở tay là $19,8 \%$. Kết quả cũng tương tự với nghiên cứu của Lê Thị Liễu năm 2018 thực hiện tại bệnh viện Bạch Mai ${ }^{8}$. Chủ yếu bệnh nhẩn có mức độ đau vừa với $70,3 \%$, sau đó là đau ít là $12,1 \%$ và đau nhiêu chiếm 2,2\%. Mức độ đau của người bệnh ở mức 
độ nhẹ với giá trị trung bình thang điểm VAS là $3.76 \pm 1.86$ và mức độ hạn chế vận động, cảm giác BOSTON đạt giá trị $1.34 \pm 0.56$; tương đương với kết quả nghiên cứu của Đinh Xuân Mạnh năm 2018 và Lê Thị Liễu năm 2018 89 . Kết quả điểm VAS và BOSTON tương ứng với lâm sàng khi mức độ đau bàn cổ tay không quá đau vì đau kiểu mạn tính, dai dẳng và âm ỉ.

Chúng tôi cũng khảo sát tổn thương của người bệnh ở bàn cổ tay trên siêu âm với kết quả: có $6,6 \%$ tổn thương khớp, $70,3 \%$ tổn thương gân gấp; 2,2\% tổn thương gân dạng dài duỗi ngắn và $60,4 \%$ có tổn thương dây thần kinh giữa. Trong đó diện tích trung bình dây thần kinh giữa là $11.487 \pm 2,195 \mathrm{~mm}^{2}$. Kết qủa của chúng tôi tương tự với kết quả của Lê Thị Liễu năm 2018 tại bệnh viện Bạch $\mathrm{Mai}^{8}$ với diện tích dây thần kinh giữa là $11,9 \pm 4,4 \mathrm{~mm}^{2}$.

Khi khảo sát các yếu tố liên quan đến tổn thương cổ bàn tay của bệnh nhân chúng tôi nhận thấy có sự liên quan của các yếu tố dịch tễ, tiền sử và sự kiểm soát đường huyết đển tổn thương khớp, gân gấp và dây thần kinh giữa. Tuy nhiên không có sự liên quan đến tổn thương gân dạng dài duỗi ngắn. Với tổn thương khớp: những người thừa cân sẽ có tổn thương khớp bàn cổ tay gấp 3,048 lần so với những người bệnh không bị thừa cân (95\%CI: 1,571-16,262). Người có tiền sử tăng huyết áp sẽ có tổn thương khớp chỉ bằng 0,118 lần người không bị $(95 \% \mathrm{CI}$ : 0,021-0,667). Người bệnh kiểm soát đường huyết và chỉ số HbA1c chưa tốt sẽ có tổn thương khớp bàn tay nhiều gấp 1,036 lần $(95 \% \mathrm{CI}$ : $1,017-5,994)$ và 1,208 (95\%CI: 1,02-6,971) lần so với người kiểm soát tốt. Đối với tổn thương gân gấp: Những bệnh nhân dưới 69 tuổi có tổn thương gân gấp chỉ bằng 0,392 lần người từ 70 tuổi trở lên $(95 \% \mathrm{CI}: 0,155-0,99)$ và những người mắc bệnh dưới 5 năm có tốn thương gân gấp chỉ bằng 0,433 người mắc bệnh trên 5 năm $(1,016-$ $1,167)$. Với những người bệnh có tiên sử tăng huyết áp có tổn thương gân gấp cao gấp 4,13 lần so với những người không có tiền sử này (95\%CI: 1,178-14,483). Người bệnh kiểm soát đường huyết chưa tốt sẽ tổn thương gân gấp cao gấp 1,204 lần so với những người kiểm soát tốt đường huyết (95\%CI: 1,047-3,081). Còn với tổn thương dây thần kinh giữa: Người bệnh có thời gian mắc bệnh dưới 5 năm có tổn thương dây thần kinh giữa chỉ bằng 0,805 lần $(95 \%$ CI: $1,309-2,099)$ so với người mắc trên 5 năm. Và người thừa cân sẽ có tổn thương gấp 1,125 lần so với người không thừa cân (95\%CI: 1,031-2,938).
Người bệnh đái tháo đường quan trọng nhất là kiểm soát mức đường huyêt và chỉ số $\mathrm{HbA1c}$. Khi kiểm soát tốt hai yếu tố trên thì tình trạng bệnh và các biến chứng sẽ được hạn chế. Với khảo sát của chúng tôi, các bệnh nhân không kiểm soát tốt đường huyết và chỉ số HbA1c đều có tổn thương nhiều hơn các bệnh nhân kiểm soát tốt.

\section{KẾT LUẬN}

1. Tỷ lệ và đặc điểm các tổn thương bàn tay ở bệnh nhân đái tháo đường type 2 .

- Tỷ lệ tổn thương bàn cổ tay ở bệnh nhân đái tháo đường typs 2 là $8,63 \%$.

- Đặc điểm tổn thương vùng bàn cổ tay ở bệnh nhân đái tháo đường type 2: Chủ yếu gặp tổn thương gân gấp $(70,3 \%)$, tổn thương dầy thần kinh giữa $(60,4 \%)$.

2. Một số yếu tố liên quan đến các tổn thương vùng bàn cổ tay

Các yếu tố liên quan đến tổn thương vùng bàn cổ tay ở bệnh nhân đái tháo đường type 2 là: tình trang kiểm soát đường huyết, chỉ số HbA1c, tuổi , thời gian mắc bệnh, tiên sử tăng huyết áp và thừa cân béo phì.

\section{TÀl LIỆU THAM KHẢO}

1. Phạm Hoài Anh (2003), Nghiên cứu rối loạn chuyển hoá lipid máu ở bệnh nhân đái tháo đường týp 2 điều trị tại Bệnh viện Đa khoa Trung ương Thái Nguyên, Luận văn Thạc sỹ Y học, Trường Đại học Y khoa Thái Nguyên.

2. Crispin JC, Alcocer-Varela J. Rheumatologic manifestations of diabetes mellitus. American Journal of Medicine. 2003;114:753-757.

3. Arkkila PE, Gautier JF. Musculoskeletal disorders in diabetes mellitus: An update. Best Practice and Research Clinical Rheumatology. 2003;17:945-970.

4. Tariq Ahmed Bhat and el-al (2016). The Musculoskeletal Manifestations of Type 2 Diabetes Mellitus in a Kashmiri Population. International Journal of Health Sciences. 2016 Jan; 10(1): 57-68.

5. Suzan M. Attar (2012). Musculoskeletal manifestations in diabetic patients at a tertiary center. Libyan J Med, 2012; 7:10.

6. American Diabetes Associantion (ADA) (2015), Standards Of Medical Care in Diabetes., Diabetes Care, chủ biên.

7. International Diabetes Federation (IDF), truy cập ngày 21st June 2017, tại trang web http:// www.Diabetessatlas.org/ content / what- is-diabetes.

8. Lê Thị Liê̂u (2018), "Nghiên cứu đặc điểm lâm sàng, điện cơ và siêu âm Doppler năng lượng trong hội chứng ổng cổ tay", Luận án Tiến sĩ Y học. Đại học Y Hà Nội.

9. Đînh Xuân Manh (2018), Nghiên cứu đăc điểm siêu âm Dopplèr năng lượng tổn thương gẩn vùng bàn cổ tay ở bệnh nhân đái tháo đường, Đại học Y Hà Nội. 